\title{
DeKalb family makes Monsanto pay market valuation
}

The heirs to DeKalb Genetics (DeKalb, IL) decided to sell their controlling interest in the family business in early February. Although the company is facing eight litigation cases involving genetically altered crops, the family cited "estate planning needs" when announcing their decision. The board responded by placing DeKalb's assets and available stock up for sale on the open market, thereby denying $40 \%$ stockholder Monsanto (St. Louis, MO) first right of refusal and pushing the stock price up significantly.

DeKalb Genetics, a 90-year-old seed and livestock company, was founded by Tom Roberts. Although it has been a public company since 1970 , the Roberts family has remained the majority voting shareholder with $56 \%$ of the Class A shares. In March 1996, DeKalb CEO Bruce Bickner negotiated a corporate partnership deal with Monsanto whereby DeKalb was paid $\$ 159$ million for $10 \%$ of the Class A voting shares and enough Class B nonvoting shares for a $40 \%$ stake. Part of the agreement gave the first right of refusal of the Roberts' controlling shares to Monsanto, but on the condition that the board did not put the company up for sale on the open market.

In the first 4 days following the announcement of the sale, DeKalb's Class B stock soared almost $100 \%$ to $\$ 65$ per share, resulting in a price tag of at least $\$ 2.3$ billion for the entire company. The sale "allows DeKalb to see its true value in the open marketplace and what its worth is to various players," says Jim Badger, director of communications at DeKalb.

Seed companies are greatly needed by biotechnology concerns in order to move novel plants to the marketplace-as illustrated by Dupont's $\$ 1.7$ billion investment in Pioneer HiBred (Des Moines, IA) last September (Nature Biotechnology 15:824, 1997). DeKalb's existing distribution channels provide a buyer with the means to bring biotechnology to the farm. In addition, the purchase price of DeKalb includes its $12 \%$ share of the $\$ 1.5$ billion US corn-seed market (second to the $42 \%$ held by its much larger competitor, Pioneer Hi-Bred), a growing soybean division, the corporate headquarters, all six research locations (including the biotechnology laboratories in Mystic, CT), six seed production plants in lowa, and a swine-genetics division in several worldwide locations.

Based on current deals in agriculture biotechnology, the short list of potential buyers, created by DeKalb officials, includes Monsanto, Novartis (Basel, Switzerland), AgrEvo (Berlin), Dow Chemical (Midland,

Debra Robertson is a freelance writer working in San Diego, CA.
MI), Cargill (Minneapolis, MN), and DuPont (Wilmington, DE).

Monsanto, which clearly holds the lead position, is "considering whether it may buy the stock it does not own", according to company officials. As well as already owning $40 \%$ of DeKalb stock, Monsanto clearly has a commitment to agriculture biotechnology: In addition to its research and licensing agreements with DeKalb, Monsanto has moved aggressively into agriculture biotechnology over the last 2 years with the purchase of a controlling interest in Calgene (Davis, CA; producer of the Flavr Savr transgenic tomato), the purchase of gene-gun technology from Agracetus (Middleton, WI), and the acquisitions of Asgrow Seed (Sentis, France) and Holden's Foundation Seed company (Williamsburg, IA).

Novartis AG currently holds $8 \%$ of the corn market. The addition of DeKalb's $12 \%$ would make Norvartis a major player in agriculture seed and would provide access to DeKalb's proprietary transgenic plants. Bioscience Securities (Orinda, CA) analyst Christine McCracken suggests that AgrEvoa joint venture between Hoechst $A G$ (Frankfurt) and Schering AG (Berlin)should also be interested in DeKalb. Although AgrEvo has developed corn plants resistant to its own Liberty herbicide, it has no seed division. In addition, purchase of Dekalb would remedy the current patent dispute between AgrEvo and Dekalb over Monsanto's Roundup herbicide-resistant corn.

As part of an already existing technology agreement, DeKalb and Monsanto produce and sell crops that are resistant to Monsanto's Roundup herbicide. John Wilbur, an analyst at Salomon Smith Barney, suggests that Monsanto will not gain greatly, in terms of access to revenues, by purchasing DeKalb, and could actually benefit from the sale of DeKalb to a larger company such as Novartis. "Monsanto currently receives $50 \%$ of the cropbased revenue from the partnership and about another $25 \%$ from its $40 \%$ stake in the company," says Wilbur. "Buying the rest of the company would simply mean that Monsanto would pay to get access to a revenue stream they are already getting $75 \%$ of." In addition, the use of the genetically altered plants developed by DeKalb and Monsanto by another buyer is dependent on access to the herbicideresistance technology owned by Monsanto. If Monsanto was bought out as part of the deal, the company would still receive revenue from the crop partnership.

Merrill Lynch is currently handling all bids with no specific timetable for the sale of the company, but estimates that bids will be entertained over the next 3 to 6 months. DeKalb stresses that the highest bid is not the only criteria for sale of the company, citing the formation of an in-house committee to assess such issues as the treatment of existing employees and renovation of the company headquarters.

DeKalb officials insist that the timing of the Roberts family's decision was not influenced by the $\$ 70$ million patent infringement lawsuit brought against Monsanto and DeKalb by Mycogen (San Diego) (Nature Biotechnology 16:230, 1998). The jury determined that Mycogen's patents describing the formation of $B t$ resistant plants were invalid-protecting both Monsanto and DeKalb from paying potential damages to Mycogen. "I think it is a coincidence that all these things are happening now. More people would have asked that question if we had lost," says Badger, "but we won." DeKalb is facing eight pending litigation cases involving genetically altered crops.

Debra Robertson

As Nature Biotechnology went to press, Monsanto president Hendrick Verfaillie said Monsanto would be a "very aggressive bidder for Dekalb," and that he expected the winning deal to be completed in 8 to 10 weeks.

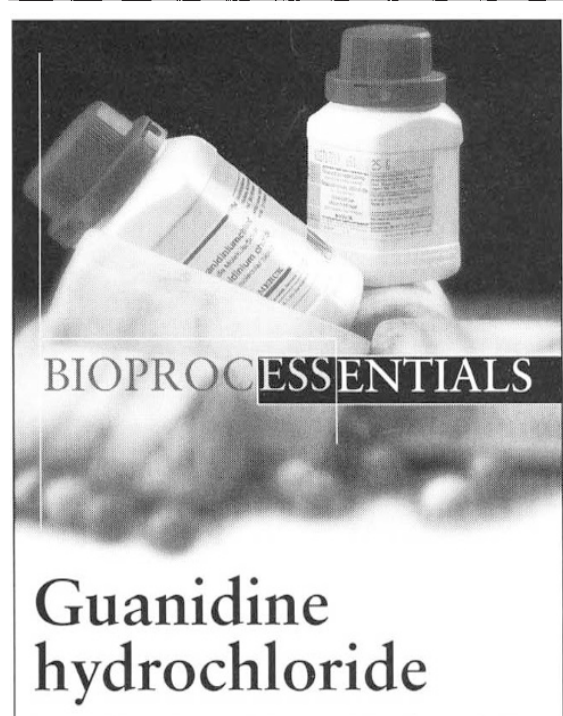

is used in substantial quantities for isolating and denaturing proteins. Our special "for molecular biology" grade is highly suitable for the extraction of RNA and the preparation of high molecular DNA. In contrast to many other producers, we manufacture guanidine hydrochloride ourselves. This guarantees high and constant quality and enables us to provide it at a fair price - whether in gram or ton quantities.

Merck KGaA Darmstadt · Germany 